\title{
Examination of Social Economic Impact on the Energy Consumption of Myanmar
}

\author{
Sim Sy Yi, Goh Hui Hwang, Ili Najaa Aimi Binti Mohd Nordin, Ling Chin Wan, Goh Kai Chen, \\ Sim Ga Yi
}

\begin{abstract}
Southeast Asia country are mostly classified as developing country. One of the aspects that ASEAN concern is the energy poverty problem. Based on the statistics known, around 127 million people in the SEA facing lack of access of electricity. Besides that, 228 million people highly depending traditional biomass to fulfil their daily needs. Myanmar is one of the sixth poorest country in the SEA. The access of electricity in Myanmar are low and experience slow improvement over a decade. Energy policy had been drafted and implemented by Myanmar government. However, the result is no significant. This paper aims to analyze the social economic impact on the energy consumption of Myanmar. The aspect of analyze include energy use, foreign direct investment, population growth, industry value added, GDP per capita growth and trade. Multivariate analysis method adopts which includes descriptive statistics analysis, unit root test, Johannsen cointegration analysis, vector error correction model and Granger causality test. The result shows unidirectional Granger causality for energy consumption with all the aspects. Analyzed data play important role in the future policy planning. Policies such as renewable energy policy, reducing energy prices, taxes and subsidies can help in increasing energy consumption which will bring up other social economic.
\end{abstract}

Index Terms: energy policy; energy poverty; granger

\section{INTRODUCTION}

Southeast Asia (SEA) is the part of Asia which covert up $8.5 \%$ of the world population. SEA country consists of Brunei, Cambodia, East Timor, Indonesia, Laos, Malaysia, Myanmar, Philippines, Singapore, Thailand and Vietnam [1]. Most of the SEA country is developing country whereby an organization has been established to seek for cooperation among member to achieve improvement. Association of Southeast Asian Nations (ASEAN) been established since 1967 and till now all SEA country participating expect East

Revised Manuscript Received on August 18, 2019

Sim Sy Yi, Faculty of Engineering Technology, Universiti Tun Hussien Onn Malaysia, Parit Raja, 86400 Batu Pahat, Johor. Universiti Tun Hussien Onn Malaysia, Parit Raja, 86400 Batu Pahat, Johor.

Ili Najaa Aimi Binti Mohd Nordin, Faculty of Engineering Technology, Universiti Tun Hussien Onn Malaysia, Parit Raja, 86400 Batu Pahat, Johor.

Ling Chin Wan, Faculty of Electrical \& Electronic Engineering, Universiti Tun Hussien Onn Malaysia, Parit Raja, 86400 Batu Pahat, Johor.

Goh Kai Chen, Faculty of Technology Management \& Business, Universiti

Tun Hussein Onn Malaysia, Parit Raja, Batu Pahat, Johor, Malaysia.

Sim Ga Yi, Faculty of Electrical \& Electronic Engineering, Universiti Tun Hussien Onn Malaysia, Parit Raja, 86400 Batu Pahat, Johor. causality.

Goh Hui Hwang, Faculty of Electrical \& Electronic Engineering,

Timor [2].

One of the aspects that ASEAN concern is the energy poverty problem $[3,4]$. Based on the statistics known, around 127 million people in the SEA facing lack of access of electricity. Besides that, 228 million people are still depending traditional biomass to fulfil their daily needs [International energy agency. Southeast asia outlook 2015].

In the year 2013, ASEAN Energy Market integration (AEMI) had been launched to overcome the problem of energy poverty in the region. Overall for the AEMI key element is enhancing the modern and clean energy accessibility and targeting several main factors which may become the catalyst to achieve the goal [5-7].

Energy poverty is not only happening in the SEA. The energy poverty also leads to a low living standard where they cannot cope up with other developed countries in all aspect. One of the obvious indicators is social economic. Social economic is refer to the relationship of social behavior with economics. Hence, both factors can affect one another. Improving the social economic enable to achieve a better standard of the living environment [8, 9]. However, the improvement had caused a certain degree of negative effect on the environment. Apparently, energy plays important role in developing the social economics of certain province or country. In another word, energy consumption is one of the major indicators of the social economic development level [10, 11].

One of the supportive evidences for this statement is the energy crisis in the year 1970 [12]. Back in 1970, energy crisis resultant of the crucial oil price. The fluctuation of oil price is catastrophic for the people where living expenses increased tremendously especially for the developing country. Developing country hardly conclude energy requirement for the nation which resultant deeply affected by the energy crisis. The energy crisis had shown the importance of energy preservation and management process $[13,14]$.

Along with the awareness on the environment, renewable energy is widely exploded. Among all the renewable sources, biomass and fuelwood are the most promises and consistent resources in any nation. In conjunction on the increase of demand due to population, renewable energy became the most promising solution for resolving energy poverty. Renewable energy also part of the electrical planning for a rural area which hardly covers by the existing power grid. 


\section{ENERGY POLICY OF MYANMAR}

Myanmar is one of the sixth poorest country in the SEA. The access of electricity in Myanmar are low and experience slow improvement over a decade. Even major citizens are frequently experiencing blackout which shows the urgent on resolving energy poverty problem in Myanmar [15, 16].

The energy consumption data of Myanmar show an increasing trend but seem cannot cope with the increase of population. Lack of electricity access reduces the usage of technology in the society which leads to a low developing nation. Only $16 \%$ of the population in rural area gain access of electricity [17]. In local, Myanmar citizen utilizes traditional biomass more than electricity [18].

The use of traditional biomass involving a lot of side effect. Combustion of plywood for cooking causing the cooker inhale fine particle that produced [19].

Myanmar government currently putting high effort on investigating the possibilities on the renewable energy to the country development [20]. The initial plan of attracting foreign investment on increasing coal-fired power plants to increase the energy production. However, the plan seems to be no widely accepted by the community due to the environmental concern. The focus is changing into hydropower [21].

As the concern toward the rural area, the local facilities are basic and traditionalize. Technology improvement had yet benefit to those who stay at rural area. Industrial still operate under traditional method due to lack to technologies expose. In long-term, problem such cannot fulfil demand may happen.

\section{LITERATURE ANALYSIS}

Numerous studies upon social economy development had been conducted. an empirical survey for Greece for the social economy determinants of energy consumption had been done [14]. The research uses energy consumption as the dependent variable which concludes the Granger causality relation to the other variables. The study outcome shows a long-term relationship between energy consumption with other variables is statically significant. Causality test showed bidirectional relationship between energy consumption and economic growth.

Cointegration study cointegration study on five of the ASEAN country by multivariate cointegration analysis [22]. The five countries are Indonesia, Malaysia, Philippines, Singapore and Thailand. The study focusing on the cointegration between energy consumption with the carbon the study is autoregressive distributed lag method. This result shows statically significant for energy consumption and carbon dioxide emission relationship in both short and long run. The author provides clear view on the ASEAN country with different economic level react upon the issue if energy consumption effect on the carbon dioxide emission or in another word means the environment.

John Asafu-Adjaye [23] investigate cointegration among energy consumption, energy prices and economic growth. The investigated country are India, Indonesia, Thailand and Philippines. Johansen cointegration test and Granger causality been used to validating causality between energy dioxide emission. The cointegration test method adopted by

consumption and income of the four Asian developing countries. Long run and short run result also been concluded as beneficial to the policy planning and forecasters.

For the study, most of the literature adopt time series analysis method to find the cointegration relation between variables. Myanmar is one of the countries where least analysis was done which belief due to the lack of raw data.

\section{DATA AND METHODOLOGY}

The data presented in this paper is adopted form World Development indicator (2016). The time series data use ranging from 2005 to 2014 which is 10 years data. Data adopted are energy use, foreign direct investment, gross domestic product per capita growth, Industry value added, population growth and trade.

The proposed energy consumption function for Myanmar is shown as a mathematical model as below. The overall study is to identify the effect of the variables to one another.

$E C \alpha=f(F D I \alpha, P O P \alpha, I N D U S \alpha, G D P \alpha, T R D \alpha)$

$\mathrm{EC}=$ Energy use $(\mathrm{kg}$ of oil equivalent per capita)

FDI = Foreign direct investment, net (BoP, current US\$)

$\mathrm{POP}=$ Population growth (annual \%)

INDUS = Industry, value added (annual \% growth)

GDP = GDP per capita growth (annual \%)

$\mathrm{TRD}=$ Trade $(\%$ of GDP $)$

This study adopts multivariate analysis method. The method includes univariate, bivariate and multivariate analysis to achieve the objective. The statistical method used is descriptive statistics analysis, unit root test, Johannsen cointegration analysis, vector error correction model and Granger causality test.

Analyses form the time series data, unit root test applies to test the stationaries properties. Two approaches of unit root test are used that is Augmented Dickey-Fuller test and Phillips-Peron test. This test is preliminary and crucial where it may affect overall analysis result.

Johannsen cointegration analysis is used to identify the existing of the cointegration relationship between the variables. The method is to perform an estimation upon the value at risk object in a group to value. Form this method, adjustment parameter value can be identified which is the need in preform vector error correction method. This test can proceed in condition at least one cointegration relation was found.

Vector error correction method applies to identify the effect on each variable involves towards the independent variable. This method enables on to quantify the effect of variables.

\section{RESULT AND DISCUSSION}

Table 1 shows the descriptive statistics for Myanmar. The understanding of actual value deviation from mean is important analysis data in the findings. For energy consumption and foreign direct investment, the standard deviation is 0.079 and 0.3069 respectively. As for gross domestic product growth rate, industrialization grow rate, population growth rate and trade (GDP\%) are $0.3,0.49,0.13$ and 2.38 respectively. 
TABLE I.

DESCRIPTIVE STATISTICS FOR MYANMAR

\begin{tabular}{|c|c|c|c|c|c|c|c|}
\hline Variables & Mean & Median & Maximum & Minimum & Std. Dev. & Skewness & Kurtosis \\
\hline EC & 5.732421 & 5.728208 & 5.985179 & 5.623948 & 0.079404 & 1.273521 \\
\hline FDI & 0.996346 & 1.004384 & 1.47313 & 0.488672 & 0.306936 & -0.16202 & 1.75833 \\
\hline GDP & 2.154964 & 2.239848 & 2.536814 & 1.488352 & 0.303194 & -0.54585 & 2.417637 \\
\hline INDUS & 2.788896 & 2.848722 & 3.652927 & 1.723737 & 0.493667 & -0.04495 & 2.269689 \\
\hline POP & -0.26995 & -0.26041 & -0.08069 & -0.4751 & 0.137978 & -0.08749 & 1.559474 \\
\hline TRD & 0.14781 & -1.36669 & 3.760563 & -1.79466 & 2.380248 & 0.685 \\
\hline
\end{tabular}

Table 2 shows the correlation test result under Pearson correlation method. From the result, energy consumption shows a statistically significant relationship with all variables. For gross domestic product growth and industrialization growth rate, energy consumption shows negative relationship but insignificant. For industrialization grow, significant positive show for gross domestic product grow while other variables are negative insignificant statistically. Foreign direct investment has a negative significant relationship with industrialization grow and gross domestic product. Even though foreign direct investment has a positive relationship with energy consumption, but the relationship is insignificant.

\section{TABLE II. CORRELATION TEST (PEARSON} CORRELATION)

\begin{tabular}{|c|c|c|c|c|c|c|}
\hline & EC & FDI & GDP & INDUS & POP & TRD \\
\hline EC & 1 & & & & & \\
\hline FDI & 0.2866 & 1 & & & & \\
\hline GDP & -0.1005 & -0.4603 & 1 & & & \\
\hline INDUS & -0.2448 & -0.5997 & 0.7389 & 1 & & \\
\hline POP & 0.5293 & 0.0898 & -0.4427 & -0.5065 & 1 & \\
\hline TRD & 0.6054 & 0.3958 & -0.6948 & -0.7226 & $\begin{array}{c}0.821 \\
6\end{array}$ & 1 \\
\hline
\end{tabular}

Unit root test is tested to avoid unreliable result or invalid result for the future cointegration analysis. The unit root test adopt for the analysis is Augmented Dickey-Fuller test and Phillips-Perron test is added to further testify the result. For a tie series data analysis, if the series found to be stationary, it means the series has a unit root.

Table 3 shows the Augmented Dickey-Fuller (ADF) test with the trend and without trend. As for the result, if the t-statistic over then the critical value can conclude that the hypothesis is been rejected. For the test only intercept, all variable has no unit root at the level. However, test for intercept and trend shows all variable stationary at level except trade grow. Hence, overall can be concluded that all variable will be stationary at level 1 .

TABLE III

AUGMENTED DiCKEY-FuLLER UNIT ROOT TEST

\begin{tabular}{|c|c|c|c|c|}
\hline \multirow{2}{*}{ Variable } & \multicolumn{2}{|c|}{ Intercept } & \multicolumn{2}{c|}{ Intercept and trend } \\
\cline { 2 - 5 } & t-Statistic & Critical & t-Statistic & Critical \\
\hline
\end{tabular}

\begin{tabular}{|c|c|c|c|c|}
\hline & & value & & value \\
\hline EC & -0.360074 & -3.639407 & 0.415577 & -4.252879 \\
\hline FDI & -2.921996 & -3.639407 & -3.072793 & -4.252879 \\
\hline GDP & -1.658285 & -3.615588 & -2.666886 & -4.219126 \\
\hline INDUS & -1.354819 & -3.632900 & -3.557271 & -4.226815 \\
\hline POP & -1.976807 & -3.670170 & -5.544056 & -4.243644 \\
\hline TRD & 0.173857 & -3.639407 & $-1.542694[1$ & $-4.296729[1$ \\
& & & & ] \\
\hline
\end{tabular}

Table 5 shows the Johansen cointegration test for the variables. From the result, proving that there is cointegration in between the variables. The result judge by if trace statistic is greater than the critical value, the null hypothesis can be rejected. The result also can be evaluated based on eigenvalue where if the value is more then 0.5 , the null hypothesis can be rejected. This test shows the possible on co-relationship between the variables. Since at least one cointegration relationship was found, this means that socio-economic factor has an alpha significant long-term impact on energy consumption.

\section{TABLE IV. $\quad$ PhILliPS-PERRON UNIT RoOT Test}

\begin{tabular}{|c|c|c|c|c|}
\hline $\begin{array}{c}\text { Hypothesize } \\
\mathrm{d} \\
\text { No. of CE(s) }\end{array}$ & $\begin{array}{c}\text { Eigenvalu } \\
\mathrm{e}\end{array}$ & $\begin{array}{c}\text { Trace } \\
\text { Statistic }\end{array}$ & $\begin{array}{c}\text { Critical } \\
\text { Value } \\
(0.05)\end{array}$ & $\begin{array}{c}\text { Prob. }^{*} \\
{ }^{*}\end{array}$ \\
\hline None $^{*}$ & 0.869024 & 142.7143 & 95.75366 & 0 \\
\hline At most 1 & 0.668488 & 73.6011 & 69.81889 & 0.0242 \\
\hline At most 2 & 0.497534 & 36.06199 & 47.85613 & 0.3932 \\
\hline At most 3 & 0.196469 & 12.6623 & 29.79707 & 0.9064 \\
\hline At most 4 & 0.142329 & 5.225159 & 15.49471 & 0.7845 \\
\hline At most 5 & 0.000146 & 0.004961 & 3.841466 & 0.9429 \\
\hline
\end{tabular}

Vector error correction modal (VECM) method use due to the existence of cointegration found in Johansen cointegration test. However, the focus of this work is on the energy consumption where the result of VECM of energy consumption will be discussed further. The result shows high R-squared value 0.809 which means there is no serial correlation for the selected variables.

Table 6 shows the energy consumption of vector error correction estimation. Energy consumption is the independent variable which is the focus of this work. The result shows statistical significance in the long run causality for both lags except 


\section{Examination of Social Economic Impact on the Energy Consumption of Myanmar}

for GDP lag 1.

Table 7 shows the Granger causality test. This test is to confirm the relationship impact between the variables. From the result, it shows that foreign direct investment, gross domestic product, trade and population have granger cause energy consumption. This means the four variables have only unidirectional relationship with the energy consumption.

TABLE V

JOHANSEN COINTEGRATION TEST

\begin{tabular}{|c|c|c|c|c|}
\hline \\
\hline \multicolumn{5}{|c|}{ Method: Least Squares (Gauss-Newton / Marquardt steps) } \\
\hline \multicolumn{5}{|c|}{ Date: 02/01/18 Time: $14: 30$} \\
\hline \multicolumn{5}{|c|}{ Sample (adjusted): 2005Q4 2014Q4 } \\
\hline \multicolumn{5}{|c|}{ Included observations: 33 after adjustments } \\
\hline \multicolumn{5}{|c|}{$\mathrm{D}(\mathrm{EC})=\mathrm{C}(1) *(\mathrm{EC}(-1)+0.248380225872 * \mathrm{FDI}(-1)-0.496110194996 * \mathrm{GDP}($} \\
\hline \multicolumn{5}{|c|}{$-1)+0.224717904671 * \operatorname{INDUS}(-1)+0.492289979577 * \mathrm{POP}(-1)-$} \\
\hline \multicolumn{5}{|c|}{$0.0674278698032 * \mathrm{TRD}(-1)-5.36747645004)+\mathrm{C}(2) * \mathrm{D}(\mathrm{EC}(-1))+\mathrm{C}(3)$} \\
\hline \multirow{2}{*}{\multicolumn{5}{|c|}{$\begin{array}{l}* \mathrm{D}(\mathrm{EC}(-2))+\mathrm{C}(4) * \mathrm{D}(\mathrm{FDI}(-1))+\mathrm{C}(5) * \mathrm{D}(\mathrm{FDI}(-2))+\mathrm{C}(6) * \mathrm{D}(\mathrm{GDP}(-1))+ \\
\mathrm{C}(7) * \mathrm{D}(\mathrm{GDP}(-2))+\mathrm{C}(8) * \mathrm{D}(\mathrm{INDUS}(-1))+\mathrm{C}(9) * \mathrm{D}(\mathrm{INDUS}(-2))+\mathrm{C}(10)\end{array}$}} \\
\hline & & & & \\
\hline \multirow{2}{*}{\multicolumn{5}{|c|}{$\begin{array}{l}* \mathrm{D}(\mathrm{POP}(-1))+\mathrm{C}(11) * \mathrm{D}(\mathrm{POP}(-2))+\mathrm{C}(12) * \mathrm{D}(\mathrm{TRD}(-1))+\mathrm{C}(13) * \mathrm{D}(\mathrm{TRD}( \\
-2))+\mathrm{C}(14)\end{array}$}} \\
\hline & & & & \\
\hline & Coefficient & Std. Error & t-Statistic & Prob. \\
\hline $\mathrm{C}(1)$ & -0.008364 & 0.069982 & -0.119520 & 0.9061 \\
\hline $\mathrm{C}(2)$ & 0.308731 & 0.322417 & 0.957554 & 0.3503 \\
\hline $\mathrm{C}(3)$ & 0.615280 & 0.304637 & 2.019718 & 0.0577 \\
\hline $\mathrm{C}(4)$ & 0.010125 & 0.024819 & 0.407962 & 0.6879 \\
\hline $\mathrm{C}(5)$ & 0.027657 & 0.025167 & 1.098937 & 0.2855 \\
\hline $\mathrm{C}(6)$ & 0.383333 & 0.154152 & 2.486722 & 0.0224 \\
\hline $\mathrm{C}(7)$ & -0.280717 & 0.238117 & -1.178901 & 0.2530 \\
\hline $\mathrm{C}(8)$ & 0.061766 & 0.035609 & 1.734577 & 0.0990 \\
\hline $\mathrm{C}(9)$ & -0.013411 & 0.025953 & -0.516737 & 0.6113 \\
\hline $\mathrm{C}(10)$ & -2.410892 & 1.308712 & -1.842187 & 0.0811 \\
\hline $\mathrm{C}(11)$ & 2.710020 & 1.476296 & 1.835689 & 0.0821 \\
\hline $\mathrm{C}(12)$ & -0.322646 & 0.189183 & -1.705471 & 0.1044 \\
\hline$C(13)$ & 0.120782 & 0.094204 & 1.282139 & 0.2152 \\
\hline $\mathrm{C}(14)$ & 0.007630 & 0.004815 & 1.584701 & 0.1295 \\
\hline R-squared & 0.804756 & Mean dependent var & & 0.005572 \\
\hline Adjusted R-squared & 0.671169 & S.D. dependent var & & 0.019963 \\
\hline S.E. of regression & 0.011448 & Akaike info criterion & & -5.805639 \\
\hline Sum squared resid & 0.002490 & Schwarz criterion & & -5.170757 \\
\hline Log likelihood & 109.7930 & Hannan-Quinn criter. & & -5.592020 \\
\hline F-statistic & 6.024176 & Durbin-Watson stat & & 2.633998 \\
\hline Prob(F-statistic) & 0.000252 & & & \\
\hline
\end{tabular}


TABLE VI.

VECM OF ENERGY CONSUMPTION

\begin{tabular}{|c|c|c|c|}
\hline Null Hypothesis: & Obs & F-Statistic & Prob. \\
\hline FDI does not Granger Cause EC & 38 & 4.15352 & 0.0246 \\
\hline EC does not Granger Cause FDI & & 0.50349 & 0.6090 \\
\hline GDP does not Granger Cause EC & 38 & 3.97710 & 0.0284 \\
\hline EC does not Granger Cause GDP & & 0.41767 & 0.6620 \\
\hline INDUS does not Granger Cause EC & 38 & 3.28270 & 0.0501 \\
\hline EC does not Granger Cause INDUS & & 0.99933 & 0.3790 \\
\hline POP does not Granger Cause EC & 38 & 4.72949 & 0.0156 \\
\hline EC does not Granger Cause POP & & 0.61196 & 0.5483 \\
\hline TRD does not Granger Cause EC & 34 & 4.72812 & 0.0167 \\
\hline EC does not Granger Cause TRD & & 3.02595 & 0.0640 \\
\hline GDP does not Granger Cause FDI & 38 & 0.40654 & 0.6692 \\
\hline FDI does not Granger Cause GDP & & 0.57386 & 0.5689 \\
\hline INDUS does not Granger Cause FDI & 38 & 0.00177 & 0.9982 \\
\hline FDI does not Granger Cause INDUS & & 0.04701 & 0.9541 \\
\hline POP does not Granger Cause FDI & 38 & 0.28269 & 0.7556 \\
\hline FDI does not Granger Cause POP & & 0.28530 & 0.7536 \\
\hline TRD does not Granger Cause FDI & 34 & 3.47059 & 0.0445 \\
\hline FDI does not Granger Cause TRD & & 2.98648 & 0.0662 \\
\hline INDUS does not Granger Cause GDP & 38 & 6.02859 & 0.0059 \\
\hline GDP does not Granger Cause INDUS & & 3.53912 & 0.0405 \\
\hline POP does not Granger Cause GDP & 38 & 2.94300 & 0.0667 \\
\hline GDP does not Granger Cause POP & & 0.41438 & 0.6641 \\
\hline TRD does not Granger Cause GDP & 34 & 15.5816 & 3.E-05 \\
\hline GDP does not Granger Cause TRD & & 13.8037 & $6 . \mathrm{E}-05$ \\
\hline POP does not Granger Cause INDUS & 38 & 1.45893 & 0.2471 \\
\hline INDUS does not Granger Cause POP & & 0.79900 & 0.4583 \\
\hline TRD does not Granger Cause INDUS & 34 & 2.38914 & 0.1095 \\
\hline INDUS does not Granger Cause TRD & & 2.53634 & 0.0966 \\
\hline TRD does not Granger Cause POP & 34 & 0.74309 & 0.4845 \\
\hline POP does not Granger Cause TRD & & 0.57096 & 0.5712 \\
\hline
\end{tabular}

\section{ConClusion}

The study examines the cointegration between energy consumption with the social economy. Social economy variables included is foreign direct investment, gross domestic product per capita growth, Industry value added, population growth and trade. Besides that, the case study only refers to Myanmar. The result showed positive statistically significant on the cointegration analysis. Unit root test with ADF and PP clearly test the stationary of the variables. The Johansen cointegration test show at least one cointegration exist which further the analysis by VECM. Lastly, Granger causality test concludes the direction of Granger causality for each variable towards one another.

The study finding shown unidirectional Granger causality for energy consumption with foreign direct investment, gross domestic product, trade and population. This information beneficial in contribute idea for policy analysis and forecaster. High energy consumption will lead to the increase of foreign direct investment, gross domestic product, trade and population growth. Policy such as renewable energy policy, reducing energy prices, taxes and subsidies can help in increasing energy 
consumption which will bring up other social economic. Besides that, the finding of single-equation regression provides foundation for forecaster on econometric forecasting.

\section{ACKNOWLEDGMENT}

The authors would like to thank the Ministry of Science, Technology and Innovation, Malaysia (MOSTI), and the Office for Research, Innovation, Commercialization, Consultancy Management (ORICC), Universiti Tun Hussein Onn Malaysia (UTHM) for financially supporting this research under the Science Fund grant No.S023 and IGSP Vot. U242.

\section{REFERENCES}

1. Worldmeter. Available from: http://www.worldometers.info/world-population/south-eastern-asia-popu lation/.

2. Irvine, R., The formative years of ASEAN: 1967-1975, in Understanding ASEAN. 1982, Springer. p. 8-36.

3. Karki, S.K., M.D. Mann, and H. Salehfar, Energy and environment in the ASEAN: challenges and opportunities. Energy Policy, 2005. 33(4): p. 499-509.

4. Sovacool, B.K., et al., Evaluating energy security performance from 1990 to 2010 for eighteen countries. Energy, 2011. 36(10): p. 5846-5853.

5. Andrews-Speed, P. and A. Hezri, V. Institutional and governance dimensions of AEMI. ASEAN Energy Market Integration (AEMI): From Coordination to Integration, 2013: p. 149-173.

6. Chirathivat, S., C. Sabhasri, and A. Chongvilaivan, Global Economic Uncertainties and Southeast Asian Economies. 2015: Institute of Southeast Asian Studies.

7. Navarro, A.M., M.T. Sambodo, and J.L. Todoc, Energy Market Integration and Energy Poverty in ASEAN. 2013, PIDS Discussion Paper Series.

8. Giddings, B., B. Hopwood, and G. O'brien, Environment, economy and society: fitting them together into sustainable development. Sustainable development, 2002. 10(4): p. 187-196.

9. Sovacool, B.K., The political economy of energy poverty: A review of key challenges. Energy for Sustainable Development, 2012. 16(3): p. 272-282.

10. Hartono, D. and B.P. Resosudarmo, The economy-wide impact of controlling energy consumption in Indonesia: An analysis using a Social Accounting Matrix framework. Energy Policy, 2008. 36(4): p. 1404-1419.

11. Allcott, H., Social norms and energy conservation. Journal of public Economics, 2011. 95(9-10): p. 1082-1095.

12. Chapman, D., T. Tyrrell, and T. Mount, Electricity demand growth and the energy crisis. Science, 1972. 178(4062): p. 703-708.

13. Rocks, L. and R.P. Runyon, The energy crisis. 1972.

14. Azam, M., et al., Socio-economic determinants of energy consumption: An empirical survey for Greece. Renewable and Sustainable Energy Reviews, 2016. 57: p. 1556-1567.

15. Sovacool, B.K., Confronting energy poverty behind the bamboo curtain: A review of challenges and solutions for Myanmar (Burma). Energy for Sustainable Development, 2013. 17(4): p. 305-314.

16. Li, K., et al., Energy poor or fuel poor: What are the differences? Energy Policy, 2014. 68: p. 476-481.

17. Worldbank, 2015.

18. Sovacool, B., Environmental conservation problems and possible solutions in Myanmar. Contemporary Southeast Asia: A Journal of International and Strategic Affairs, 2012. 34(2): p. 217-248

19. Kyaw, W.W., et al., Energy utilization and the status of sustainable energy in Union of Myanmar. Energy Procedia, 2011. 9: p. 351-358.

20. 20. Nam, K.-Y., W.M. Cham, and P.R. Halili, Power sector development in Myanmar. 2015.

21. Dobermann, T., Energy in Myanmar. 2016.

22. Chandran, V. and C.F. Tang, The impacts of transport energy consumption, foreign direct investment and income on $\mathrm{CO} 2$ emissions in ASEAN-5 economies. Renewable and Sustainable Energy Reviews, 2013. 24: p. 445-453.

23. Asafu-Adjaye, J., The relationship between energy consumption, energy prices and economic growth: time series evidence from Asian developing countries. Energy economics, 2000. 22(6): p. 615-625.

\section{AUTHORS PROFILE}

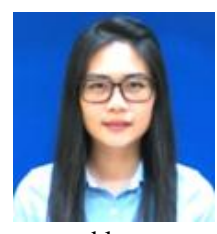

Sim Sy Yi received the B.Eng degree in electrical engineering and $\mathrm{Ph} . \mathrm{D}$ degree in electrical from Universit Tun Hussein Onn Malaysia (UTHM) in 2012 and 2016, respectively. Currently, she is a lecturer in Universiti Tun Hussein Onn Malaysia (UTHM). Her current research interests include of power electronic, artificial intelligent, renewable energy and power system.

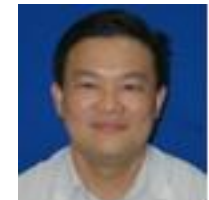

Goh Hui Hwang received his B.Eng degree in electrical engineering and M.Eng degree in electrical from Universiti Teknology Malaysia (UTM) in 1998 and 2003, respectively. Then he received his $\mathrm{Ph} . \mathrm{D}$ degree in Universiti Teknologi Malaysia (UTM) in 2007. Currently, he is an associate professor in Universiti Tun Hussein Onn Malaysia (UTHM). His current research interests include of power system, artificial intelligent, renewable energy and renewable energy policies.

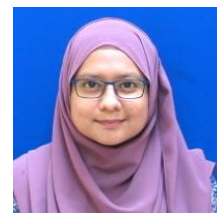

Ili Najaa Aimi Binti Mohd Nordin received his B.Sc. in Electrical Engineering (Medical) from Universiti Teknologi Malaysia in 2011 and graduated in same university with a PhD in Electrical Engineering in 2016.

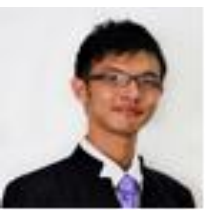

Ling Chin Wan received the B.Eng degree in electrical engineering and M. Eng degree in electrical from Universiti Tun Hussein Onn Malaysia (UTHM) in 2014 and 2016, respectively. Currently, he is pursuing the $\mathrm{Ph} . \mathrm{D}$. degree at the Department of Electrical and Electronic Engineering, Universiti Tun Hussein Onn Malaysia (UTHM). His current research interests include of power electronic, renewable energy, artificial intelligent and renewable energy policies.

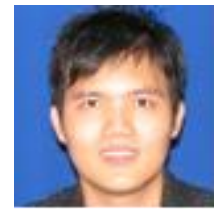

Goh Kai Chen received the B.Eng degree in science and M.Eng degree in science (construction management) from Universiti Teknology Malaysia (UTM) in 2005 and 2006, respectively. Then he received his $\mathrm{Ph} . \mathrm{D}$ degree in Queensland University of Technology in 2011. Currently, he is an associate professor in Universiti Tun Hussein Onn Malaysia (UTHM). His current research interests include of environment sustainable construction.

Sim Ga Yi received his B.Eng. (Electrical Engineering) from Universiti Tun Hussien Onn Malaysia (UTHM) in 2018. She is currently pursuit Master in Universiti Tun Hussien Onn Malaysia. 